\title{
Jaringan Komunikasi tentang Inovasi Obyek dan Strategi Kelompok Pengemis di Kampung Padangan di Kota Solo
}

\author{
Sutopo JK \\ Universitas Sebelas Maret Surakarta Kentingan No 36 A Surakarta \\ Email:sutopojk@gmail,com
}

\begin{abstract}
To understand beggars in Solo was insufficient by just seeing the poverty. Beggars phenomena can be seen from any aspects of life for instances mentality, motivation, poverty, ill modernity, education, and including power relation. This research is to explore how beggar community in Solo to survive by developing objects innovation and strategy. This also expose how each of beggars joins and connects to control one of areas compared with others. By in depth interviews and focus group of discussion, this research disclose the communication networking among beggars and deep structure covered the power relation. The results showed us that beggars community communicated to other community. They shared of innovation and strategies to get new target and new areas. It was commonly found that the communication networking among beggars community was available in hierarchy in which determine who is the boss and who is the follwers and loyalty. These findings was usefull for government including social organization and government to rescue and rehabilitate them in order to get dignity by working properly not beg in the street or cross road in Solo.
\end{abstract}

Keywords: Communication network, Beggar community, poverty, object innovation and strategy

\begin{abstract}
Abstrak
Untuk memhamai pengemis di Solo tidak mencukui jika hanya melihat persoalan kemiskinan. Fenomena pengemis dapat dilihat dari sejumlah aspek kehidupan seperti mentalitas, motivasi, kemiskinan, penyakit modernisasi, pendidikan dan termasuk relasi kuasa. Riset ini untuk mengeksplore bagaimana komunitas pengemis di Solo untuk bertahan hidup dan eksis dengan mengembangkan objek inovasi dan strategi. Penelitian juga mengungkapkan bagaimana komunitas pengemis saling berkomunikasi dan berhubungan satu dengan yang lain untuk berbagai terhadap objek inovasi dan strategi untuk mendapatkan sasaran baru dan area yang baru. Dalam penelitian ini ditemukan adalah struktur hirarki dalam komunitas para pengemis itu yang menentukan siapa yang menjadi bos dan siapa yang menjadi pengikut dan loyalis. Hasil penelitian semacam ini berguna untuk pemerintah dan organisasi sosial yang ada untuk dapat melakukan pemberdayaan dan pemahaman bahwa bekerja adalah lebih baik dibandingkan dengan melakukan pengemisan di jalan dan perempatan jalan raya di Solo.
\end{abstract}

Kata kunci: Jaringan komunikasi, komunitas pengemis, kemiskinan, objek inovasi dan strategi. 


\section{Pendahuluan}

Memahami kemiskinan bukan merupakan masalah ukuran kuantitatif, tetapi kemiskinan sebagai suatu masalah sosial yang menembus setiap dimensi budaya dan masyarakat. Menurut Bartle (2009 :2) kemiskinan meliputi tingkat pendapatan yang terus menerus untuk anggota suatu masyarakat, kurangnya akses terhadap layanan seperti pendidikan, kesehatan, pasar kurangnya fasilitas seperti air bersih, sanitasi dan transportasi.

Tak sedikit yang menyesalkan kemerdekaan Indonesia. Justru mereka yang terjerat kemiskinan ingin negeri ini dijajah saja oleh bangsa asing. Bagi mereka yang penting, tidak ada kemiskinan, tidak ada kekurangan dimanapun, dan tak ada kekecewaan asal perekonomian terpenuhi dan kesejahteraan terwujudkan (Sutopo, 2012:2).

Walaupun pembangunan di Kota Solo terus dipacu, sehingga berdiri hotel, mall, swalayan dan berbagai lembaga ekonomi lainnya, dengan biaya yang sangat tinggi tak selalu memberikan dampak positif. Dampak negatifnya adalah masalah kepadatan penduduk dan jumlah kemiskinan di Solo. Semakin banyaknya manusia otomatis semakin banyak pula keperluan dalam kehidupan mereka masingmasing.

Di tengah-tengah pesatnya pembangunan di wilayah Solo ada salah satu kampung yaitu kampung Padangan, Kelurahan Joyotakan, Kecamatan Serengan, Kota Solo, sebagian besar warganya sumber penghidupannya sebagai Pengemis. Dalam kegiatannya sehari-hari para pengemis ini selalu mengemis ke luar kampung.

Pada sore dan malam mereka berinteraksi (berkomunikasi) dengan anggota kelompok pengemis lainnya antara lain membicarakan hasil karya mengemis (hasil emisan). Dalam komunikasi kelompok pengemis, mereka saling menceritakan dan semacam laporan kepada teman lainnya, sehingga kalau itu dianggab berhasil maka teman lainya pada hari yang akan datang juga dipraktekan. Begitu juga dalam pertemuan antara para pengemis itu juga ada kesepakatan-kesepakatan tentang areal atau wilayah yang harus disasar atau. dijadikan obyek mengemis. Mereka membicarakan sesuatu yang baru yang dalam pemikiran mereka sebagai inovasi mengemis.

Sebuah inovasi mempunyai arti sesuatu yang baru apabila: (1) Menciptakan sesuatu yang baru yang sebelumnya belum ada,(2) menciptakan sesuatu yang barui dari yang sudah ada,(3) memperbarui sesuatu dari yang sudah ada (Sudikno;1986:23). Dengan demikian di dalam sumber penghidupan mengemispun juga ada yang inovatif baik obyek-obyek yang dimintai maupun strategi mengemis. Obyek-obyek di sini siapa yang pantas dimintai dan dimana serta bagaimana cara mengemisnya. Dari hasil interaksi (komunikasi) diantara para pengemis inilah yang melahirkan inovasi mengemis.

Keputusan mengadopsi suatu inovasi terjadi melalui proses yang tidak hanya terletak pada satu aspek individu saja. Peran jaringan sosial dalam penelitian ini adalah kelompok pengemis di dukuh Padangan menentukan perilaku adopsi inovasi. Proses komunikasi yang terjadi antara individu-individu yang tergabung dalam kelompok.

Pengemis membentuk arus pertukaran informasi yang terpola kemudian membentuk suatu jaringan komunikasi. Akibat dari interaksi yang terjadi dalam jaringan komunikasi kelompok pengemis ini terjadi pertukaran informasi tentang obyek-obyek yang dimintai dan sekaligus

strategi mengemisnya yang kemudian dapat mempengaruhi proses adopsi jaringan komunikasi sekaligus juga dapat menunjukkan orang-orang (para anggota pengemis) yang mempunyai peranan penting dalam sistem tersebut.

Untuk itu penelitian dilakukan dengan menggunakan 4 analisa jaringan komunikasi dengan harapan dapat diketahui sosiogram kelompok pengemis tersebut. Seberapa luas jaringan dan sistem individu dan klik juga dapat terungkap. Pertanyaan pentingnya adalah apakah menjadi seorang pengemis itu ada 
yang menggerakkan atau adanya mitos yang menyatakan sebagai kodratnya sebagai seorang pengemis.

Asumsi dasar dalam penelitian ini adalah: (a) Setiap manusia memiliki kharakteristik masingmasing sesuai dengan lingkungan disekitarnya; (b) Manusia sebagai makhluk sosial, hidup bermasyarakat dan tak lepas dari interaksi sosial; (c) Dalam berinteraksi sosial manusia harus berkomunikasi dengan baik, sehingga pesan dapat disampaikan dengan baik dan mengurangi terjadinya miss communication yang menyebabkan terjadinya miss understanding dalam berkomunikasi; dan (d) setiap kelompok yang tinggal dalam suatu daerah yang sama memiliki budaya yang spesifik. Pola-pola komunikasi itu didekati dengan pendekatan Teori Konvergensi yang membentuk Jaringan Komunikasi (Sutopo,2013: 23)

Dalam kajian ini, manfaat penelitian ini diarahkan pada dua hal, yakni pertama untuk mengetahui bagaimana pola Jaringan Komunikasi tentang inovasi obyek-obyek pengemis dan strateginya pada kelompok pengemis di Kampung Padangan, Kecamatan Serengan, Solo. Kedua, berguna untuk mengetahui karakteristik anggota sistem para pongemis itu mempengaruhi jaringan komunikasi dalam kelompok pengemis itu.

Aktivitas komunikasi adalah proses penyampaian pesan oleh seseorang kepada orang lain untuk memberi tahu atau untuk mengubah sikap, pendapat, perilaku, baik secara lisan, maupun langsung melalui suatu media. Hal yang penting dalam komunikasi adalah bagaimana cara yang dilakukan komunikator agar pesan yang ia sampaikan dapat menimbulkan efek tertentu pada komunikan

Model komunikasi linier memiliki banyak keterbatasan dan kekurangan, maka model komunikasi linier mendapatkan kritikan-kritikan dari para ahli. Berikut adalah beberapa kritik terhadap model komunikasi linier:

1. Merupakan suatu pandangan komunikasi yang linier, satu arah serta bukan siklis, berproses dua arah secara terus-menerus.
2. Sumber kesalahan terletak pada dependensinya diantara para partisipan komunikasi dan tidak mengakui hubungan-hubungan serta saling keterkaitan diantara mereka.

3. Ada kecenderungan melihat obyekobyek komunikasi kelewat sederhana, obyek yang secara fisik terpisah dan mengabaikan konteks di dalam mana obyek tadi berada

4. Terlalumemusatkan perhatian sematamata terhadap pesan dan mengabaikan hal-hal yang penting sehubungan dengan pesan tadi seperti tanda baca dan hal-hal lain yang memberikan kejelasan waktu ketika pesan tadi disampaikan.

5. Cenderung menganggap bahwa fungsi utama komunikasi adalah persuasi dan tidak menganggap fungsi-fungsi lain seperti pemahaman bersama.

6. Terlalu memusatkan pada efek-efek sosial serta hubungan antar individu dengan individu lainnya dalam suatu jenjang sosial.

7. Lebih menekankan atas satu arah dan mekanistis (daripada asas kebersamaan) yang menjadi ciri sistem-sistem informasi antara manusia yang sebenarnya adalah kibernetis sifatnya

Pada perkembangannya muncul model komunikasi konvergensi. Model konvergensi ini pertama kali dikemukakan oleh seorang filsuf yaitu Charles Sanders Peirce. Pengertian Peirce menangkap dua prinsip dasar yang mendasari model konvergensi yaitu bahwa informasi sudah menjadi sifat yang tidak tepat dan tidak menentu, dan komunikasi adalah sebuah proses dinamis dari perkembangan yang terus menerus.(Kusrini;2010:34). Esensi dan model konvergensi adalah:

1. Memandang semua komponen komunikasi termasuk para partisipan sebagai suatu kesatuan yang saling tidak terpisahkan satu dengan yang lain. Semua unsur dipandang sebagai suatu sistem yang menyeluruh (holistik) dan 
tidak pernah terpisahkan (atomistik).

2. Komunikasi sebagai suatu proses adalah tidak memiliki titik awal dan titik akhir. Proses komunikasi selalu diawali dengan —dan kemudian... $\square$ yang berarti sebelum kita mengamati suatu tindakan atau kegiatan komunikasi sebenarnya sudah berlangsung rangkaian proses yang tidak kita ketahui yang telah dilakukan oleh partisipan komunikasi. Dan komunikasi juga tidak punya titik akhir, melainkan berlanjut terus menerus tanpa ${ }^{\wedge}$ berhenti dalam siklus penyampaian dan penerimaan informasi yang silih berganti diantara partisipan (McFarlane, 2010)

3. Sifat dinamik, dalam artian memberikan kemungkinan pemikiran terhadap konteks, tujuan, maksud, gerakan dan perubahan dalam proses saling berbagi atau pertukaran informasi menuju pengertian bersama, kesepakatan bersama dan tindakan bersama.

Kontak informasi (yaitu jaringan), ketidaktentuan, dan tujuan adalah elemen kunci dari penjelasan sibernetik. Komponenkomponen dari model konvergensi menjadi dinamis dengan penambahan prinsip dasar dari penjelasan sibernetik. Information circuits (that is, networks), uncertainty, and purpose are the key elements of cybernetic explanation. The components of the convergence model become dynamic with the addition of the basic principles of cybernetic explanation.(Rogers and Kincaid, 1981:57)

Konvergensi setiap pemahaman peserta komunikasi dengan peserta komunikasi lainnya tidak pernah lengkap, tidak pernah sempurna Kode dan konsep yang salah satunya tersedia untuk pemahaman dipelajari melaluijpengalaman. Pemahaman bersama adalah sebuah proses penghubungan keputusan berdasarkan ketidak pastian

Gambar model konvergensi tersebut menggambarkan pertemuan dasar pemahaman bersama dan siklus dasar dari pertukaran informasi. Komunikasi konvergensi merupakan dasar dari jaringan komunikasi. Jaringan merupakan salah satu cara untuk memahami perilaku manusia Sedangkan perilaku manusia di sini dimaksudkan untuk memahami hubunganhubungan sosialnya yang tercipta karena adanya proses komunikasi interpersonal. Hubungan antara individu dalam suatu sistem dimana mereka saling mengirim informasi (bertukar informasi), hal ini membentuk suatu jaringan ( Sutopo JK ;2011:34).

Jaringan komunikasi adalah saluran yang digunakan untuk meneruskan pesan dari satu orang ke orang lain. Jaringan ini dapat dilihat dari dua perspektif. Pertama, kelompok kecil sesuai dengan sumber daya yang dimilikinya akan mengembangkan pola komunikasi yang menggabungkan beberapa struktur jaringan

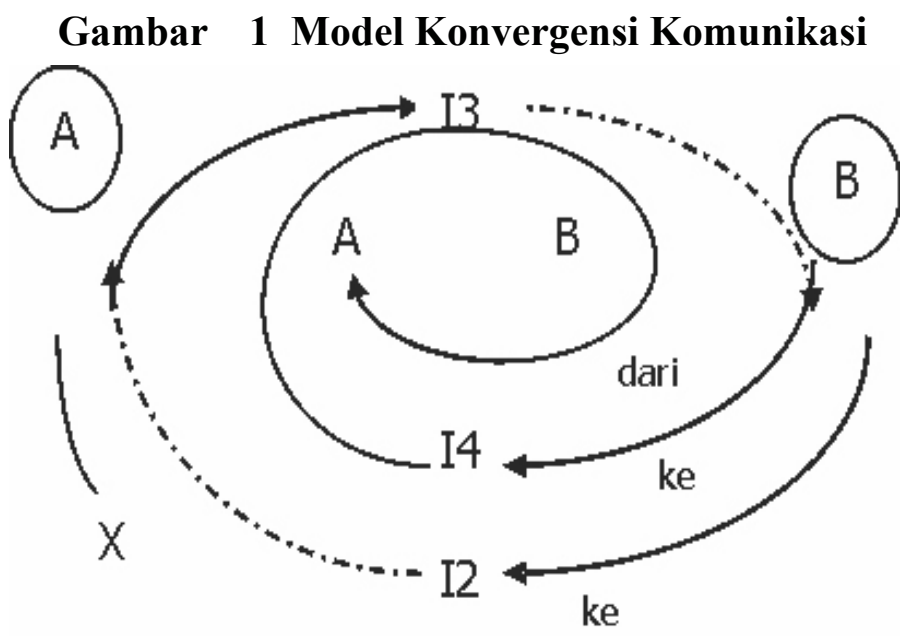


komunikasi. Jaringan komunikasi ini kemudian merupakan sistem komunikasi umum yang akan digunakan oleh kelompok dalam mengirimkan pesan dari satu orang ke orang lainnya. Kedua, jaringan komunikasi ini bisa dipandang sebagai struktur yang diformalkan yang diciptakan oleh organisasi sebagai sarana komunikasi organisasi (Eriyanto: 2014:2).

Analisis jaringan komunikasi menggambarkan hubungann yang tercipta karena adanya pembagian (pemberian, pertukaran) informasi. Jaringan komunikasi terdiri dari individu-individu yang saling berhubungan yang dihubungkan oleh arus komunikasi yang terpola.Rogers dan Kincaid menyatakan bahwa analisis jaringan komunikasi merupakan sebuah metode penelitian untuk mengidentifikasi struktur komunikasi dalam sebuah sistem, yang mana keterhubungan data tentang komunikasi yang terjadi dianalisis dengan menggunakan beberapa tipe hubungan interpersonal sebagai unit analisisnya. Analisis jaringan komunikasi biasanya terdiri dari satu atau lebih prosedur penelitian sebagai berikut:

1. Identifikasi klik dalam sistem keseluruhan dan menetapkan bagaimana bagianbagian struktur mempengaruhi perilaku komunikasi dalam sebuah sistem.

2. Identifikasi peranan dari masing-masing bagian seperti liaisons, bridges, dan isolates.

3. Mengukur berbagai indeks struktur komunikasi untuk tiap individu, diadik, jaringan personal klik, atau keseluruhan sistem.

Klik adalah bagian dari sistem (sub sistem) dimana anggota-anggotanya relatif lebih sering berinteraksi satu sama lain dibandingkan dengan anggota-anggota lainnya dalam sistem komunikasi. Selain itu untuk mengidentifikasi apakah individu dapat dimasukkan ke dalam suatu klik atau tidak, terdapat tiga kriteria yang digunakan, yaitu:
1. Setiap klik minimal harus terdiri dari 3 anggota.

2. Setiap anggota klik minimal harus mempunyai derajat keterhubungan $50 \%$ dari hubungan-hubungannya di dalam klik.

3. Seluruh anggota klik baik secara langsung maupun tidak langsung harus saling berhubungan melalui suatu rantai hubungan dyadic yang berlangsung secara kontinyu dan menyeluruh di dalam klik. Melalui analisis jaringan dapat diketahui peran masing-masing individu di dalam jaringan komunikasi tersebut. Peran seseorang dalam sebuah jaringan komunikasi bervariasi.

\section{Metode Penelitian}

Penelitian ini menggunakan metode kualitatif yaitu sebagai penelitian yang menghasilkan data deskriptif berupa kata tertulis atau lisan dari orang-orang dan perilaku yang diamati (Bogdan,1983:3). Pendekatan ini diarahkan pada latar belakang dan individu secara holistik. Strategi penelitian studi kasus adalah suatu inkuiris empiris yang menyelidiki fenomena kontemporer di dalam konteks kehidupan yang nyata, bilamana batas-batas antara fenomena dan konteks tak tampak dengan tegas, dan dimana multi sumber bukti dimanfaatkan (K.Yin,2004:18). Studi kasus memungkinkan peneliti untuk mengadakan penelitian secara mendetail dengan mempertahankan karakteristik holistik dan bermakna dari peristiwa-perisrtiwa dikehidupan nyata yang diteliti.

Obyek dan Lokasi Penelitian dalam penelitian ini, adalah penduduk miskin yang sumber penghidupannya sebagai pengemis di Kampung Padangan RT04 RW 03 Kelurahan Joyontakan, Kecamatan Serengan Kota Solo. Di samping juga akan mewawancarai para narasumber yang mengusai permasalahan penelitian tersebut.

Warga yang menjadi informan dalam penelitian ini memiliki beberapa kualifikasi antara lain: Anggota kelompok pengemis dan 
warga pengemis atau orang miskin yang tercatat sebagai warga setempat dan termasuk golongan usia produktif 25-50 tahun. Disamping itu juga narasumber warga Solo yang mengetahui permasalahan dan tinggal di pos-pos pengemis di wilayah Kota Solo seperti di perempatan "Nggeblekan, proliman perempatan pasar Kliwon dan perempatan Laweyan serta tempat-tempat lain yang sering untuk istirahat para pengemis di wilayah Solo maupun wilayah Solo Baru."

Jumlah penduduk miskin yang berprofesi sebagai pengemis di Kampung Padangan RT 03/RW 04 Kelurahan Joyontakan, Kecamatan Serengan, Kota Solo sebanyak 33 Kepala Keluarga. Adapun teknik pengambilan sampelnya dengan sensus dimana semua populasi dijadikan sampel. Hal ini sesuai dengan persyaratan metodologi dalam analis jaringan komunikasi harus dengan sisten sensus agar tidak terputus arus informasinya.

Data yang digunakan terdiri dari dua jenis data yaitu: data primer dan data sekunder, sedangkan pengumpulan datanya dengan cara in-depth interview dan observasi, dokumentasi dan Fokus Group Discusion.

\section{Hasil dan Pembahasan}

Usia pengemis sebagian besar $(22,50 \%)$ pada usia 30-34 tahun, usia 25- 29 tahun sebesar $15 \%$ dan yang berusia $40-44$ tahun ada 12,5 $\%$ selanjutnya usia 45-49 tahun ada $10 \%$. Dengan demikian para pengemis kalau dilihat dari aspek umur semua pengemis masih pada usia produktif. Sejak kapan mulai mengemis data di lapangan menunjukan sebagian besar ada $35 \%$ mulai mengemis sejak kecil/ anak, karena diajak orang tua atau neneknya. Mereka yang mengaku mengemis sejak 5 tahun yang lalu ada $27,5 \%$ dan yang mengaku mulai mengemis 10 tahun yang lalu ada $20 \%$. Lingkungan sumber penghidupanya sebagai pengemis sangat berpengaruh kepada anak-anak untuk diajak mengemis.

Mengenai alasan ikut mengemis data lapangan menunjukan bahwa alasan mengemis sebagian besar (37,5\%) mengaku ikut orang tua /Warisan/disuruh orang tua/sejak kecil melanjutkan yang telah dilakukan neneknya. Sedangkan yang mengaku tidak ada pekerjaan lain (kepepet) ada 32,5\%. Anak-anak diajak mengemis utamanya pada saat liburan sekolah atau hari libur.

Menurut tokoh masyarakat (Ketua RW ) di kampung Padangan, Kelurahan Joyontakan, Kecamatan Serengan Kota Solo untuk mengetahui penyebab kenapa kampung Padangan sebagian besar sebagai pengemis, harus melihat sejarah para penduduk di Kelurahan Joyotakan ini yaitu sejak dahulu para pengemis sudah tinggal di kampung tersebut. Dari mitos, dahulu di kampung ini ada orang Sakti yang bernama Joyoantoko yang dimakamkan di Jatiagung. Para pengikutnya banyak yang taat dan setia melakukan protes ke Kraton Surakarta. Raja Kraton Surakarta kepada para pengikutnya pernah mengatakan: besuk sak turunannya akan menjadi pengemis. Dari nilai-nilai itulah sampai saat ini seolah-olah menjadi faktor yang melunturkan semangat kerja keras dalam rangka mempertahankan hidupnya.

Hal ini sangat berbeda dengan orang miskin yang tinggal di tepian rel kereta api dan kelompok miskin yang tinggal di tepian Sungai. Bagi orang miskin di kedua lokasi itu berprinsip kita hidup atau tinggal di lahan bukan miliknya ini, dalam rangka mempertahankan hidup harus kerja keras apa saja asal halal bahkan mereka berprinsip - ora obah ora mamah (Sutopo,2012)

Bagi pengemis di lokasi penelitian ini seorang ibu menceriterakan kepada peneliti bahwa mereka mengemis ini sebenarnya siapa tho yang dirugikan kok orang podo iri itu! Sebab kami ini dalam keadaan sepi saja dapat uang sebanyak Rp 20.000,- dengan tidak usah kerja keras dapat untuk menghidupi keluarganya. Wong sejak dulu-dulu nenek-nenek saya juga jadi pengemis semua. Kenapa orang podo iri/ srei dengan kami-kami apa lagi itu lho Satpol PP sering merasia kami.

Lebih lanjut ibu itu mengatakan bahwa 
berdasarkan pengalamanya waktu digaruk sudah beberapa kali, setelah digaruk kami dingkut dinaikan mobil SATPOL PP paling hanya ditanyai dan terus kami dikembalikan ke Kelurahan Joyotakan dan oleh Pak Lurah diberi pengarahan terus suruh kembali dan disuruh cari pekerjaan lain saja. "Lha saya tanya siapa yang mau memberi pekerjaan saya, oke saya mau ikut saja. Saya tanya tidak ada yang memberi solusi. Begitulah berkali-kali kami digaruk jalan keluarnya hanya itu-itu saja."

Menurut Pak Juwarno Ketua RW 03 dan sekaligus sebagai Modin di Kelurahan Joyotakan, ia selalu mengingatkan dan memberi nasehat. " Sewaktu saya ada kesempatan nyambut pidato dalam acara kematian, orang punya kerja atau di mimbar jum'at selalu saya singgung bahwa meminta-minta itu halal saja, tetapi di dalam agama Islam itu bukan yang diajarkan atau diharapkan selain tidak mendidik anak juga dari segi harga diri kurang — kajen".

Bahkan dengan tegas dikatakan bahwa tangan di atas itu akan lebih baik dari pada tangan di bawah. "Kenapa berkali-kali kami tegaskan, ya sebab kalau saya mengisi khotbah Jum'at dan kultum di hari Ramadan itu banyak ibu yang sumber penghidupannya mengemis, yang sholat berjamaah di Masjid. Apa lagi kalau bulan puasa banyak ibu pengemis yang juga sholat Tarweh dan Sholat Fitr bersama di Mushola di Masjid Kelurhan itu."

Dari seorang ibu pengemis, ketika dikonfirmasikan tentang apa yang disampaikan Ketua RW. Mereka mengafirmasi bahwa memang betul Pak RW melakukan hal tersebut. "Itu sering menyindir-nyindir kami tetapi menurut saya ngomong saja mudah melakoni. Ini tho pak yang kondisinya seperti kami-kami ini susah himbauan Pak RW itu dilakoni sebab kami ini pendidikan SD saja tidak lulus. Apa nggak susah to Pak kan enak ngemis saja."

Menurut pendapat tokoh masyarakat di wilayah kelurahan Joyotakan yang tidak mau di sebut namanya, mengatakan bahwa akibat sabdo ratu tersebut sebenarnya yang mengemis saat ini tinggal cucu, buyut dan canggah.
Artinya memang pengemis di Dukuh Padangan ini merupakan "tetesan wahyu pengemis" dari leluhurnya dahulu, sehingga logis kalau faktor itulah yang menjadi melunturkan kerja keras, untuk dapat mempertahankan hidupnya. Sementara itu menurut tokoh masyarakat lainnya menilai bahwa walaupun ibu-ibu sumber penghidupannya sebagai pengemis tetapi dari segi kemasyarakatan terlihat sangat bagus dalam memperingati 17 Agustusan, bergotong royong dan apa lagi kalau ada yang punya hajatan rasa kesetiakawananya terlihat sangat bagus.

Jika dibandingkan dengan karakteristik pengemis di Jakarta, para pengemis Jakarta tersebut dikoordinasi oleh kelompok terstruktur yang disebut mafia Pengemis, namun yang terjadi di Solo tidak ada mafia atau yang menggerakan. Karakteristik yang menonjol yang terjadi di Solo adalah ada unsur gerakan kebersamaan, saling toleransi, tidak struktur organisasi, tetapi hanya gerakan spontan dan saling pengertian serta rasa kesetiakawananya sangat tinggi. Pola kerja bagi pengemis di Jakarta dikoordinir oleh mafia pengemis yang bertugas nenjaga keamanan bagi para pengemis, dari pihak Pemerintah Daerah (Satpol PP) maupun gangguan dari para preman dan kelompok destruktif lainnya. Adapun pembagiannya untuk pihk mafia pengemis bagiannya $60 \%$ dan $40 \%$ bagian pengemis. Kalau si pengemis kena garukan si Boss harus bertanggung jawab untuk segera melakukan tindakan bagaimana caranya agar pengemis secepatnya dapat dikeluarkan.

Perbedaan yang menyolok lainnya adalah pengemis di Jakarta, sewaktu pergi dan pulang memakai pakaian yang bagus, selanjutnya di tempat atau di lokasi tertentu mereka berganti pakaian khusus untuk mengemis. Menurut para ahli dibidang sosial, fenomena pengemis tidak mudah diberantas sebab ada kerja sama simbio materialistis yaitu kerja sama antara boss dengan petugas tertib kota.

\section{Inovasi Strategi Mengemis}

Strategi mengemis merupakan hal yang sangat dipertimbangkan karena akan sangat besar 
pengaruhnya terhadap pendapatan pengemis. Strategi mengemis yang paling banyak dilakukan adalah memakai pakaian compang camping sebesar $25 \%$. Dengan menggunakan pakaian seperti itu orang kaya benar-benar menganggap mereka sebagai orang yang tidak punya dan akan timbul kasihan sehingga diberi uang. Strategi yang lain mengemis adalah secara kelompok yakni $17,5 \%$ dengan jumlah kelompok antara 3 s/d 10 orang tentu termasuk anak kecil yang diajak. Strategi ini dipakai karena donatur atau si BOSS sudah punya jadwal tertentu dan si punya rumah juga sudah menyiapkan receh (uang pecahan ), sehingga agar tidak menyulitkan yang punya rumah tidak terkesan bolak-balik.

Tingkat pendidikan pengemis sebagian besar belum lulus SD, sedangkan yang lulus SD juga sangat kecil hanya $35 \%$. Selain sebagai pengemis, mereka juga punya pekerjaan sampingan sebagian besar $(42,5 \%)$ menjadi pekerja bubut/merangkai kain bekas dan ada yang mengaku menjadi pekerja srabutan apa saja asal halal.

Berbicara mengenai pendapatan pengemis sebagian besar pendapatannya setiap hari (47,5\%) antara Rp 10.000 s/d Rp 20.000 dan yang mengaku pendapatan perhari antara Rp 20.000 s/d 30.000,- ada 45\%.. Uang sebesar itu untuk dapat hidup di kota Solo sudah cukup, bahkan menurut pengakuanya mereka masih dapat menabung walaupun sedikit.

\section{Pola Jaringan Komunikasi Pengemis.}

Manusia sebagai makhluk sosial selalu berhubungan dengan manusia yang lain. Saat menjalin hubungan dengan orang lain, secara langsung mereka melakukan tindakan komunikasi. Dengan demikian dalam hubungan-hubungan itu terbentuk pola jaringan komunikasi. Melalui jaringan komunikasi itulah terbentuk, seseorang mendapatkan informasi yang ia perlukan. Akan tetapi dalam memperoleh informasi seseorang akan memilih orang-orang tertentu yang dipercayai atau ia sering bertemu dengan mereka bahkan bisa juga orangorang yang dekat atau yang seprofesi.

Penelitian yang menggunakan analisa jaringan komunikasi bertujuan untuk mengidentifikasi struktur jaringan komunikasi dan untuk memahami gambaran umum mengenai interaksi yang terjadi antar manusia di dalam sistem dalam hal ini kelompok pengemis. Dalam menganalisa data digunakan metode sosiometri. Prosedur yang digunaka di sini masih menggunakan cara manual yang menggunakan 3 perangkat analisis yaitu matrik sosiometri, sosiogram dan indeks sosiometri (Puspanjani, 2012L66). Sebenarnya sekarang juga sudah ada program penggunaan Ucinet dengan alamat https://sites.google.com/site/ucinetsoftware/

\section{Data Penelitian Jaringan Komunikasi Pengemis}

\begin{tabular}{|c|c|c|c|c|}
\hline No & No Individu & Dipilih & Memilih & $\begin{array}{l}\text { Kontak Person } \\
\text { dengan individu }\end{array}$ \\
\hline 1 & $\# 1$ & $\begin{array}{l}\# 2, \# 4, \# 5, \# 22, \# 24, \# 29 \\
\# 30, \# 31, \# 32,\end{array}$ & $\begin{array}{l}\# 2, \# 11, \# 14, \# 22, \# 23, \# 28 \\
\# 30, \# 32, \# 39\end{array}$ & $\begin{array}{l}\# 2, \# 4, \# 5, \# 11, \\
\# 14, \# 22, \# 23, \# 24, \# 28 \\
\# 30, \# 31, \# 32, \# 39\end{array}$ \\
\hline 2 & $\# 2$ & $\# 1, \# 3, \# 8, \# 9$ & $\# 1$ & $\# 1, \# 3, \# 8, \# 9$ \\
\hline 3 & 3 & - & 2 & 2 \\
\hline 4 & 4 & 13 & 1 & 1,13 \\
\hline 5 & 5 & $\begin{array}{l}6,7,10,37,11,13,14 \\
22,23,25,31\end{array}$ & $1,19,26,27,35,39$ & $\begin{array}{l}1,6,7,10,11,13,14 \\
19,22,23 \\
25,26,27,31 \\
35,37,39\end{array}$ \\
\hline 6 & 6 & - & 5 & 5 \\
\hline 7 & 7 & 23 & $5,22,28$ & $5,22,23,28$ \\
\hline
\end{tabular}




\begin{tabular}{|l|l|l|l|l|}
\hline No & No Individu & Dipilih & Memilih & $\begin{array}{l}\text { Kontak Person } \\
\text { dengan individu }\end{array}$ \\
\hline 8 & 8 & 16 & $2,22,23,28,29$ & $2,16,22,23,28,29$ \\
\hline 9 & 9 & $25,22,23$ & 2 & $2,22,23,25$ \\
\hline 10 & 10 & 22, & 5,24 & 5,24 \\
\hline 11 & 11 & 1,12 & $5,1,30,33$ & $1,5,12,30,33$ \\
\hline 12 & 12 & 13 & 11 & 11,13 \\
\hline 13 & 13 & 12,14 & $4,5,12$ & $4,5,12,14$ \\
\hline 14 & 14 & 1,15 & $1,5,13,17$ & $1,5,13,15,17$ \\
\hline 15 & 15 & $23,17,28$ & $14,29,16,18,21$, & $14,16,17,21,23$, \\
\hline 16 & 16 & $8,15,20$ & $8,17,18$ & 8,29 \\
\hline 17 & 17 & $14,33,36,38,16$, & $15,30,38$ & $8,15,18,20$ \\
\hline 18 & 18 & $18,19,21,26,27,28,34$ & & $14,15,16,18,19,21$, \\
\hline 19 & 19 & $15,16,27$ & $17,19,20,21$ & $30,33,34,36$ dan 38 \\
\hline 20 & 20 & $5,18,16,21,27$ & 17,20 & $15,16,17,19,20,21,27$ \\
\hline 21 & 21 & $19,18,38$ & 21 & $5,16,17,1820,21,27$ \\
\hline 22 & 22 & $15,17,18,20$ & 17,19 & $18,19,21,38$ \\
\hline 23 & 23 & $1,7,8$ & $5,9,10$ & $15,17,18$ dan 19,20 \\
\hline 24 & 24 & $1,8,15$ & $5,7,9$ & $1,5,7,8,9$ dan 10 \\
\hline 25 & 25 & 10,40 & 1 & $1,5,7,8,9$ \\
\hline 26 & 26 & 9 dan 40 & 5 & $1,10,40$ \\
\hline 27 & 27 & 5,29 & 17,40 & 5,9 dan 40 \\
\hline 28 & 28 & 5,18 & 17,19 & $5,17,29,40$ \\
\hline 29 & 29 & $1,7,8,29$ & $1,26,28$ & $5,17,18$ dan 19 \\
\hline 30 & 30 & $7,8,15$ & $1,11,32,34$ & $1,7,8,1517,29$ \\
\hline 31 & 31 & $1,17,33,35,36,37,38,39$ & $1,17,32,33,26$ dan 28 \\
\hline 32 & 32 & $1,36,37$ & $5,38,40$ & $1,5,36,37,38$ dan 40 \\
\hline 33 & 33 & 17,11 & 1,30 \\
\hline
\end{tabular}

\section{Sumber : Diolah dari data Primer tahun 2013}

home_(Eriyanto, 2014:290).

Menurut Model Negopy matrik sosiometri terdiri dari sebuah tabel dimana dalam deret dan kolom memperliharkan pilihan sosial dari anggota kelompok. Nama dari responden yang memilih (siapa-Who) dicatat dalam kolom (vertikal) dan pilihan mereka (ke siapa -to whom ) dicatat secara horizontal dalam deret. Matrik sosiometri disebut juga matrik siapa kepada siapa (Who to Whom)
Tahap berikutnya adalah menyusun sosiogram untuk menunjukkan pola-pola komunikasi atau hubungan pilihan sosial dalam suatu sistem sosial yang disusun berdasarkan matriks whom to whom dari pertanyaan pertanyaan sosiometri. Dalam penelitian ini, data-data untuk menganalisis struktur jaringan komunikasi diperoleh melalui pertanyaan sosiometri no: 5 dan pertanyaan no 6 dalam kuestiner yang diajukan kepada para narasumber. 
Jawaban atas pertanyaan sosiometri tersebut menunjukkan hubungan yang terjalin antar individu karena informasi tentang inovasi yang ingin diperolehnya. Dari data di lapangan setelah dilakukan identifikasi sampai ke delapan, ternyata hasilnya seperti sosiogram diatas.

Dengan mengacu analisis Jaringan Komunikasi, memang tidak disebutkan harus ke berapa tetapi dengan tegas dinyatakan bila identifikasi dari ke 7 dan ke 8 sudah stabil dalam arti hanya sedikit perubahan saja, maka mengurutkan skor atau letak responden berkomunikasi secara stabil, sehingga akan di dapat implementasi pola komunikasi yang sesungguhnya di suatu sistem tersebut seperti pada diagram dibawah.

Pada gambar berikut di atas tampak jelas bahwa ranking komunikasi para di Kampung Padangan.

Dari 40 narasumber, ada 6 individu yang memiliki link paling banyak. Mereka adalah individu \#5, individu \#1, \#17,\# 30 ,\# 18

\section{Sosiogram Jaringan Komunikasi tentang Inovasi Obyek dan Strategi Pengemis}

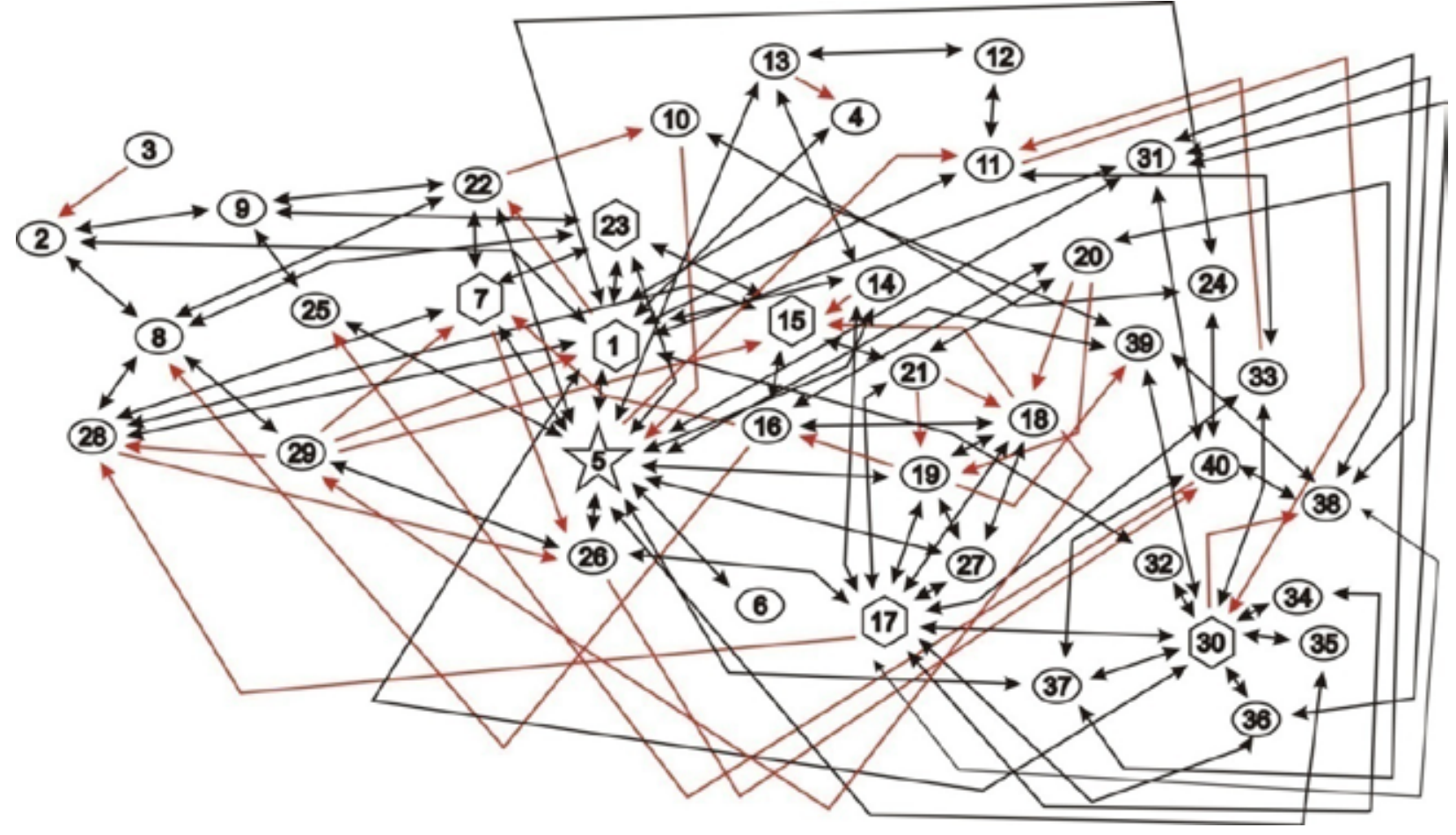

Keterangan:



identifikasi dilakukan sampai ke delapan. Meksipun begitu, peneliti juga telah mencoba sampao ke 9, justru yang terjadi pecah lagi, maka identifikasi ke 8 itulah dihentikan sebagai gambar yang terakhir dan sudah stabil.

Identifikasi itu, digunakan untuk

$$
\begin{gathered}
\qquad=\text { Star } \\
\Delta=\begin{array}{c}
\text { Negketee (individu yang memilih tetapi } \\
\text { dipilih) }
\end{array}
\end{gathered}
$$

dan Individu \# 28. Individu \# 5, dengan nama Sri Lestari di kalangan Pengemis lebih akrap dipanggil Sari dalam sosiogram itu berperan sebagi star sebab mendapat anak panah sebanyak 17 (paling banyak).

Dalam kesehariannya Ibu ini memiliki 


\begin{tabular}{|l|l|l|}
\hline No Responden & Jumlah konteks komunikasi & Pilihan konteks \\
\hline$\# 5$ & 17( star) & $\begin{array}{l}\# 26, \# 35, \# 37, \# 6, \# 27, \# 19, \# 39 \\
, \# 31, \# 11, \# 10, \# 23, \# 13, \# 1, \# 4, \\
\# 22, \# 7, \# 25\end{array}$ \\
\hline$\# 1$ & 14 (Pemuka Pendapat) & $\begin{array}{l}\# 5, \# 32, \# 14, \# 31, \# 11, \# 4, \# 23, \# \\
24, \# 22, \# 2, \# 28, \# 29, \# 30, \# 36\end{array}$ \\
\hline$\# 17$ & 12 (Pemuka Pendapat) & $\begin{array}{l}\# 38, \# 34, \# 36, \# 30, \# 33, \# 27, \# 33, \# 18 \\
, \# 19, \# 21, \# 14, \# 26 .\end{array}$ \\
\hline$\# 30$ & 10 (pemuka pendapat) & $\begin{array}{l}\# 36, \# 35, \# 34, \# 11, \# 33, \# 39, \# 32, \# 17 \\
, \# 37, \# 1\end{array}$ \\
\hline$\# 18$ & $8($ Pemuka pendapat) & $\# 29, \# 20, \# 15, \# 21, \# 16, \# 19, \# 17, \# 27$ \\
\hline$\# 28$ & $7($ Pemuka pendapat) & $\# 17, \# 28, \# 29, \# 1, \# 15, \# 7, \# 8$ \\
\hline
\end{tabular}

\section{Sumber: diolah dri data Primer tahun 2013}

sumber penghidupan sebagai pengemis yang berumur 35 tahun dan statusnya sudah pisah ranjang dengan suaminya. Narasumber ini mudah bergaul dengan siapa saja, sopan dan "grapyak", sehingga sering mengajak atau berinteraksi dengan tetangganya untuk diajak mengemis. Salah satu ciri khas Ibu Sari ini kalau mengemis selalu mengajak anaknya yang masih kecil sambil di gendong kemana-mana, sehingga orang lain yang melihat "kasihan/ Iba".

Ibu Sari ini belum mempunyai rumah tinggal hanya mengontrak rumah dan tempat kontraknya selalu berpindah-pindah tetapi masih dalam satu lokasi itu. Karena itu, ia lebih banyak temannya atau kolega untuk mengemis. Individu \# 5 ini akrab berinteraksi dengan individu \#26, \#6 ,\#37 \#27, \#19, \#31, \#13, \#22 dan \# 25. Dari hasil pengamatan, individu-individu tersebut merupakan ibu-ibu pengemis yang telah usia di atas empat puluh tahun. Bahkan Individu \# 5 dan \# 27 dan individu \#19 berhubungan sangat akrab sebab ketiga individu itu pernah hidup (kost rumah) yang berdekatan.

Begitu juga individu\#5 dan \# 14 dan \# 1 (Ibu Sisri) juga termasuk membentuk hubungan yang sangat akrab. Sebab mereka bertiga merupakan status janda dan pisah ranjang, sehingga hubungan mereka sama-sama senasib dan lebih aman dan mantab sumber penghidupanya sebagai pengemis.

Secara umum jaringan komunikasi pengemis termasuk sosiogram yang terbuka dan merata karena tidak terbentuk klik kecilkecil tetapi menyatu dalam satu sistem dan semua saling berinteraksi bahkan sebagian besar berhubungan dua arah (mutual pair) terbentuk. Bahkan yang mendapatkan link terbanyakpun juga memiliki sumber penghidupannya sebagai pengemis, bahkan sangat sering mengajak atau membujuk teman-temanya.

Dengan demikian jaringan informasi itu menggambarkan bahwa mereka bergabung dalam komunitas besar pengemis atas dasar inisiatif sendiri. Artinya secara organisatoris ia tidak ada yang menggerakkan oleh oknum tertentu, tetapi hanya solidaritas antar mereka sangat kuat dan karena kebutuhan dan lingkungannya. Pandangan mereka merata bahwa mengemis ternyata juga dapat digunakan untuk menyambung / mempertahankan hidup.

Seperti penjelasan di depan bahwa mereka mengemis sejak nenek moyangnya atau neneknya, sehingga sampai sekarang seluruh keturunannya menjadi pengemis. Mereka yang 
merasa berhasil sebagai pengemis kepada warga lingkunganya berinteraksi secara bebas seperti pada sosiogram di atas.

Meskipun demikian menurut Kasubdin Bina Orogram DKRPP Kota Surakarta ada 3 macam pengemis yang beroperasi di Kota Solo, yakni pengemis yang asli penduduk Solo, pengemis yang dari luar Solo dan ada pengemis yang dikerahkan. Pernyataan ini tidak secara spesifik menunjuk pada kelompok mana yang dikerahkan. Namun apa bila mengacu kepada wawancara dengan semua responden, mereka menyatakan bahwa mereka melakukan aktivitas ini tanpa adanya pengerahan melainkan berdasarkan inisiatif mereka sendiri.

Secara teoritis kegiatan semacam ini yang bisa dikategorikan ke dalam salah satu strategi budaya kemiskinan yakni cara untuk melakukan survival mechanism bagi komunitas orangorang miskin. Barangkali adanya pengerahan seperti yang disinyalir Kasubdin Bina Program tersebut lebih tertuju pada pengemis yang sering ditemukan di perempatan-perempatan jalan yang secara fisik mereka menyandang kecatatan seperti menderita kusta dan cacat badan lainnya dimana sulit dibayangkan mereka melakukan mobilitas dalam aktivitas mereka jikalau tidak ada pihak-pihak lain yang membantu mobilitas mereka untuk sekedar bisa sampai pata tempattempat umum seperti perempatan jalan dan kepulangan mereka sehabis melakukan kegiatan mengemis.

\section{Simpulan}

Struktur dan jaringan komunikasi yang terjadi pada pengemis di Kampung Padangan ,Kelurahan Joyotakan dapat ditarik beberapa kesimpulan sebagai berikut:

1. Pola jaringan Komunikasi Pengemis di Kampung Padangan (RT04/ RW O3) di Kelurahan Joyontakan melibatkan semua anggota kelompok yang berjumlah 33 pengemis. Pola jaringan Komunikasi yang terbentuk (dalam Sosiogram) menyebar tetapi alur informasi bersumber pada beberapa individu yaitu individu \# 5
(17 link sebagai star), Individu \# 1 (14 link sebagai pemuka pendapat ), Individu \# 17 (12 link sebagai pemuka pendapat), Individu \#17 (12 link sebagai pemuka pendapat), Individu \# 30 (10 link sebagai pemuka pendapat), individu \#18 (link 8 sebagai pemuka pendapat) dan Individu \# 28 (7 Link sebagai pemuka pendapat.

2. Hasil identifikasi sampai 8 kali hingga perubahannya stabil dan dapat digambarkan sosiogram hanya terbentuk sebuah klik besar serta ditemukan 5 pemuka pendapat. Para pemuka pendapat di kalangan pengemis tersebut ternyata bukan merupakan tokoh atau pengurus kelompok pengemis. Sebab Pengemis di kampung Padangan RT 04 / RW 03 tidak ada organisasi atau pengurus pengemis, sehingga mereka hanya pengemis biasa tetapi lebih aktif dan lebih berpengalaman mengemis dengan berbagai strategi. Bagi para pengemis di wilayah ini walaupun tidak ada struktur organisasinya tetapi rasa kesetiakawanannya/kekompakan cukup tinggi. Dengan demikian Pemuka pendapat di kalangan pengemis hanya yang lebih senior dalam mengemis dan aktif mengajak teman-temannya mengemis, sebab merasa sesama senasib di kalangan mereka.

3. Peranan individu dalam jaringan komunikasi Pengemis dalam difusi inovasi dan strategi pengemis yang berperanan sebagai inovator adalah para senior pengemis itu sendiri bahkan secara konseptual mereka yang berkedudukan sebagai pemuka Pendapat pengemis itu sendiri. Mengenai pola penyebaran difusi dan strategi mengemis itu sendiri melalui jalur interaksi mereka setiap harinya baik itu di sepanjang mengemis atau sewaktu berkomunikasi harian di tempat tinggalnya masing-masing.

4. Mengenai alasan mengemis bagi sebagian warga Kampung Padangan bila dicermati dari sejarahnya yang sering menyebut- 
nyebut dari orang tuanya atau neneknya. Sebab sesuai dengan informasi dari para tokoh dan sesepuh di kampung itu di wilayah kampung itu dahulu banyak dihuni oleh orang sakti yang bernama Joyoantoko dan para pengikutnya sering melakukan protes ataupembangkangan" ke Kraton Surakarta. Oleh Raja Surakarta saat itu dicibratkan - para pemrotes keturunannya besuknya akan menjadi pengemis. Tampaknya sebagian masyarakat di wilayah ini sebagai —image atau mitos bahwa kita ini telah ditakdirkan menjadi pengemis atau tetesan wahyu pengemis, sehingga fenomena yang ada bahwa alasan mengemis selalu diajak nenek, orang tua atau tetangganya. Dari mitos itu tampaknya sangat besar pengaruhnya terhadap usaha-usaha semangat untuk bekerja lain ataupun untuk melakukan sekolah yang lebih tinggi. Oleh karena itu bila dilihat dari aspek pendidikanya para pengemis yang tidak sampai lulus SD ternyata juga cukup tinggi. Disamping itu, juga ada beberapa warga yang $\mathrm{t}$ bersal dari wilayah lain kebetulan juga banyak yang mondok di Kampung ini ,yang kebetulan juga banyak yang mengemis dengan demikian menambah kesan bahwa kampung Padangan ini sebagai pusatnya pengemis.

5. Bahwa kegiatan meminta-minta yang dilakukan oleh kelompok pengemis di kampung Padangan, Kelurahan Joyoyakan di Kota Surakarta ini hampir seluruhnya dilakukan oleh perempuan dewasa yang secara berkelompok beroperasi di beberapa Wilayah di Surakarta dan yang paling menonjol di Pasar Kliwon, Nggeblegan, Kauman dan di Laweyan.

\section{Saran-saran}

Dalam hal pembinaan atau penyebaran informasi sebaiknya dilakukan dengan mengikutsertakan semua anggota pengemis, sehingga informasi tidak berpusat pada satu atau beberapa orang saja. Hendaknya para pembina sosial juga harus sering dan aktif memberikan motivasi agar lama kelamaan mau mencari sumber penghidupan bukan lagi sebagai pengemis.

Perlu adanya tindakan dalam bentuk kebijakan pemerintah daerah untuk menangani permasalahan pengemis sebagai bagian dari permasalahan penyandang masalah kesejahteraan Sosial (PMKS) baik melalui pemerintah Daerah atau regulasi lainnya yang terkait dengan pengentasan penduduk miskin. Pemerintah Daerah Kota Solo sebaiknya segera membangun rumah singgah untuk menampung para pengemis untuk di bina dan di motivasi agar bersedia kerja yang keras tidak hanya mengandalkan belas kasihan orang lain.

Perlunya ada program ketrampilan yang ditujukan kepada para pengemis yang telah kena garukan, sehingga mereka dibina dengan ketrampilan seperti tukang las, tukang batu, menjahit dan kegiatan lainnya yang sangat praktis,sehinggga dapat sebagai sarana aleh profesi dari pengemis.

\section{Daftar Pustaka}

Bartle, 2009, Teori Komunikasi, Bandung: Rosdakarya

Eriyanto, 2014, Jaringan Komunikasi, Strategi Baru dalam Penelitian Ilmu Komunikasi dan Ilmu sosial lainnya, Jakarta: Prenada Media Group.

Mulyana, Deddy, 2005, Ilmu Komunikasi Suatu Pengantar, Bandung: Rosdakarya

Mefarlane, Donovan A. 2010, Social Communication in a Technology-Driven Society, American Communication, American Communication Journal Winter 2010 Volyume 12.

Puspanjari, Arumtyas, 2012, Pola Komunikasi Penduduk Miskin, Jakarta: Gramedia Sutopo, HB, 2009, Metode Penelitian Kualitatif, Solo: UNS Press Rogers, Everett and D.J Kincaid, 1986, 
Comunication Network Toward a New Paradigma for for Reseach, New York: Erlbaum 1983,Diffusionofinnovation. Third Edition, New York: The Free Press of Macmillan Publising

Fardhani, Fardhani, 2004, Komunikasi Masyarakat Miskin, Solo: FISIP UNS.

Sutopo, 2013, A Study of the Communication patterns of the poor comunicaties living beside the river a long side the railway tract in order to survive in the city of Solo

$\begin{array}{ccrr}\begin{array}{c}\text { central } \\ \text { and }\end{array} & \begin{array}{c}\text { Cova, Journal of } \\ \text { Comunication }\end{array} & \begin{array}{r}\text { Society } \\ \text { volume }\end{array} \\ 2013, & 266-239-293 & \text { Vol } & 13 . \\ ------, & 2010, & \text { Komunikasi } & \text { dan } \\ \text { Pembangunan, } & \text { Solo: } & \text { Jurusan } \\ \text { Ilmu Komunikasi FISIP } & \text { UNS. } \\ -----, 2009, \quad \text { Metodologi } & \text { Penelitian } \\ \text { Kuantitatif,Solo: Komunikasi FISIPUNS } \\ \text { Tubbs, Steward Land Styvia Moss, 2001, Human } \\ \text { Communication:Konteks-Konteks } \\ \text { Komunikasi, } \text { Bandung: } & \text { Rosdakarya }\end{array}$
and Communication volume 